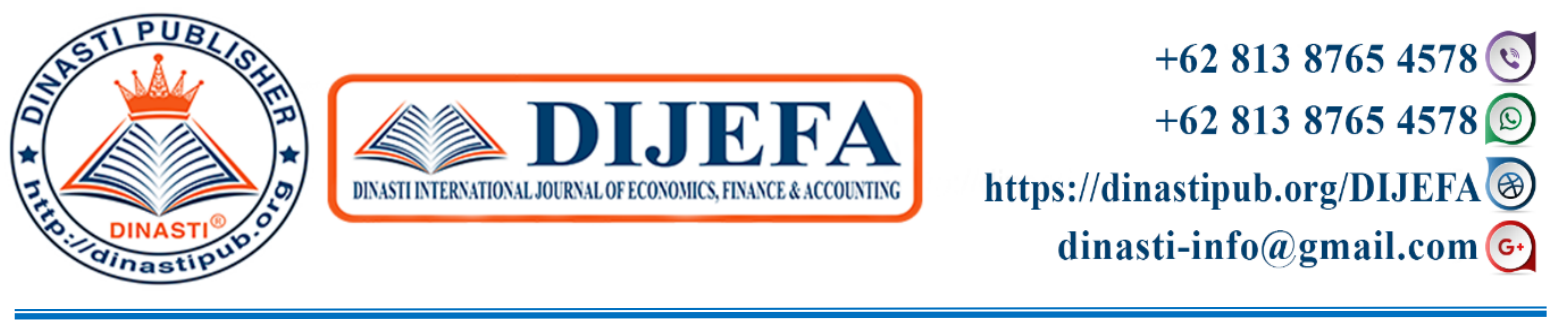

\title{
BUYING INTEREST AND TRUST MODEL: E-WOM AND BRAND IMAGE
}

Muhammad Reza Putra ${ }^{1}$, Gupron²

1) $\mathrm{Ph} . \mathrm{D}$ Student, Kebangsaan Malaysia University

${ }^{2)}$ Faculty of Business and Economic, Batanghari University Jambi, Indonesia

\begin{tabular}{c|l}
$\begin{array}{c}\text { ARTICLE INFORMATION } \\
\text { Received: 15 September 2020 } \\
\text { Revised: 25 October 2020 } \\
\text { Issued: } 5 \text { November 2020 }\end{array}$ & $\begin{array}{l}\text { Abstract: The article Buying Interest and Trust Model: } \\
\text { E-Wom Analysis and Brand Image aims to build a } \\
\text { research hypothesis using the library research method. } \\
\text { To find out the variables that affect Buying Interest } \\
\text { Online, a review of previous studies was conducted. } \\
\text { The results of this article indicate a hypothesis has been } \\
\text { built for further research that e-WOM, and Brand } \\
\text { Image, have an effect on Online Purchase Trust and } \\
\text { Interest. } \\
\text { Muhammad Reza Putra } \\
\text { Keywords: Brand Image, e-WOM, Trust, Buying } \\
\text { Interest. }\end{array}$ \\
$\begin{array}{c}\text { gupron@unail: } \\
\text { DOI: } 10.38035 / D I J E F A\end{array}$ &
\end{tabular}

\section{INTRODUCTION}

Consumers who actively use mobile applications and social networks are a form of online consumer behavior in terms of collecting information that tends to generate interest in online purchases (Kristiani et al., 2019). The behavior of online consumers in looking for product information shows a tendency to have an interest in buying before deciding to make a purchase (Han et al., 2018). There have been many previous studies examining the factors that influence online purchase intention. Buying intentions online are influenced by celebrity trust, celebrity expertise, celebrity attractiveness (Murwaningtyas et al. 2019), convenience and product quality (Indrajaya \& Ali, 2017), eWOM (Abubakar \& Ilkan, 2016; Jalilvand et al., 2017), public relations and advertisements which are part of promotions can increase interest in online purchases (Munawar \& Ali, 2017). The intention to buy online is also influenced by risk perceptions (Ariffin et al., 2018), trust (Farivar et al., 2017), and brand image (Agussalim \& Ali, 2017; Setyadi \& Ali, 2017; Ali, 2017).

In compiling relevant research articles, several theories are needed to strengthen the research model that is built and see the relationship between variables in building hypotheses 
is part of the discussion of research results. This article specifically discusses the factors that influence consumer buying interest, where this study is a literature study of marketing management. Of course not all factors influence buying interest in this article, but only some of the dominant factors will be examined in this article.

\section{Formulation of the Problem}

Based on the background described above, the problems that will be discussed are formulated to focus more on literature review, the results and discussion are to review the theory of the influence of the independent variable on the dependent variable as listed below:

1) Does EWOM have a relationship and influence on trust?

2) Does EWOM have a relationship with and influence Buying Interest?

3) Does the Brand Image have a relationship and influence to Trust?

4) Does Brand Image have a relationship and influence to Purchase Intention?

5) Does Trust have a relationship and influence to Purchase Intention?

\section{LITERATURE REVIEW}

\section{Buying Interest}

Purchase interest is something that arises after receiving stimulation from the product he sees, then the desire to buy and own it appears (Kotler \& Amstrong, 2012). Research on buying interest has been widely studied by previous studies such as research developed by (Abubakar \& Ilkan, 2016), (Erkan \& Evans, 2016), (Bataineh, 2015), (Lee et al., 2017), (Agussalim \& Ali , 2017), (Setyadi \& Ali, 2017), (Ali, 2017), (Farivar et al., 2017), (Silva et al., 2019), (Ho et al., 2017), (Larasetiati \& Ali, 2019), (Firmansyah \& Ali, 2019), (Liu \& Guo, 2017), (Mosunmola et al., 2019), (Kaur \& Quareshi, 2015), (Marriott \& Williams, 2018), (Zhao et al., 2019), (Pappas, 2018), and (Firmansyah \& Ali, 2019).

\section{EWOM}

eWOM is a dissemination of information between consumers who provide information to each other via the internet (Schiffman \& Kanuk, 2012). Research on EWOM has been widely studied by previous studies such as research developed by (Abubakar \& Ilkan, 2016), (Erkan \& Evans, 2016), (Bataineh, 2015), (Lee et al., 2017), (Bulut \& Karabulut , 2018), (Ali, 2019), (Matute et al., 2016), (Firmansyah \& Ali, 2019), and (Bhandari \& Rodgers, 2018).

\section{Brand Image}

Brand image is defined as a set of beliefs, ideas, and impressions that a person has about a brand that can influence a person's decisions (Levy \& Weitz, 2012). Research on Brand Image has been widely studied by previous research such as research developed by (Ali, 2017), (Agussalim \& Ali, 2017), (Setyadi \& Ali, 2017), (Ali, 2019a), (Firmansyah \& Ali, 2019) .

\section{Trust}

Consumer trust is defined as the knowledge that consumers have from the conclusions made about objects, attributes, and benefits (Mowen, 2012). Research on trust has been widely studied by previous research such as research developed by (Larasetiati \& Ali, 2019), (Firmansyah \& Ali, 2019), (Liu \& Guo, 2017), (Mosunmola et al., 2019), (Kaur \& Quareshi, 
2015), (Marriott \& Williams, 2018), (Zhao et al., 2019), (Pappas, 2018), (Firmansyah \& Ali, 2019), (Ali, 2019), (Agussalim \& Ali, 2017), (Ali, 2019a), (Farivar et al., 2017), (Silva et al., 2019), ((Ho et al., 2017), (Pappas, 2016), (Park et al., 2019), ( Yang et al., 2015), (Bulut \& Karabulut, 2018), (Ali, 2019), (Matute et al., 2016), and (Bhandari \& Rodgers, 2018).

\section{RESEARCH METHODS}

The method of writing scientific articles uses literature study and literature study. By reviewing various references according to the theory discussed, especially in the scope of Marketing Management. Besides, it analyzes reputable scientific articles as well as scientific articles from journals that are not yet reputable. All cited scientific articles are sourced from Mendeley and Google Scholar.

In qualitative research, literature review should be used consistently with methodological assumptions. This means that it must be used inductively so that it does not lead to the questions posed by the researcher. One of the main reasons for conducting qualitative research is that it is explorative in nature (Ali \& Limakrisna, 2013).

Furthermore, it is discussed in depth in the section entitled "Related Literature" or literature review ("Review of Literature"), as a basis for the formulation of hypotheses and will then become the basis for making comparisons with the results or findings revealed in the research. (Ali \& Limakrisna, 2013).

\section{RESULTS AND DISCUSSION}

\section{EWOM and Trust}

The research model developed by (Bulut \& Karabulut, 2018) states that the quality of eWOM and the quantity of eWOM has a positive influence on e-trust. Ali, (2019) consumer confidence can be increased with promotional activities, such as social media, newspapers, billboards, eWOM and TV advertisements. This is because eWOM positively (Abubakar \& Ilkan, 2016) and (Matute et al., 2016) significantly affect trust. Trust is a picture of purchasing behavior towards products that can be considered as a company's future competitive advantage (Firmansyah \& Ali, 2019).

\section{EWOM and Buying Interest}

Word of Mouth Marketing can greatly influence the purchasing decision process (Kotler \& Keller, 2013). eWOM is a process of dynamic and continuous exchange of information between potential, actual or experienced consumers about a product, service, brand or company, which is available to many people and institutions via the internet (Ismagilova et al., 2017). Recommendations from other customers are usually considered more trusted than promotional activities originating from companies and can greatly influence other people's decisions to use a product or service (Lovelock, 2011). Research conducted by (Abubakar \& Ilkan, 2016) states that E-wom can affect buying interest. (Erkan \& Evans, 2016) Eewom has a positive and significant effect on buying interest. (Bataineh, 2015) found that the quality of eWOM, credibility of eWOM, and quantity of eWOM have an effect on purchase intention.

\section{Brand Image and Trust}

The strong brand image in the minds of consumers will increase the trust felt by consumers in using the products they buy (Agussalim \& Ali, 2017). When consumers are 
aware that the brand that will be used has more benefits, consumers will believe (Ali, 2019a), because the brand image and company reputation that can be maintained will lead to buying behavior (Ali, 2019a). Brand image has aspects that can be formed through access to services, services offered, personal contact, security, and positive reputation that can affect consumer trust and commitment (Setyadi \& Ali, 2017). Brand image significantly influences the trust accepted by consumers (Cheong \& Jang, 2008).

\section{Brand Image and Buying Interest}

Brand image, brand awareness and price factors can positively influence the buying behavior of a product (Ali, 2019a). Where the brand image is a picture of the seller's positive reputation in the minds of consumers (Setyadi \& Ali, 2017). A strong brand image indicates that consumers will believe in the product they buy (Agussalim \& Ali, 2017). Brand image for purchasing electronic products has a positive correlation and has a significant effect on purchase intention (Kazmi \& Mehmood, 2016). The research by (Yu et al., 2013) found a positive influence between brand image and purchase intention.

\section{Trust and Buying Interest}

Consumer trust is knowledge possessed by consumers and all the conclusions made by consumers about objects, attributes, and benefits (Mowen, 2012). When consumers have confidence in other parties involved in the exchange of information on reliability and integrity, it can be said that there is trust (Kotler and Keller, 2013). Consumers' trust in various sources of information, consumers reveal that the recommended communication will run itself to be the most trusted source of information (Schiffman \& Kanuk, 2012). Research developed by (Larasetiati \& Ali, 2019) states that consumer trust will create good trust in sellers and will increase consumers in purchasing behavior. Trust has a direct and significant effect on purchase intention (Firmansyah \& Ali, 2019). Like (Liu \& Guo, 2017) that trust positively influences purchase intention. Mosunmola et al. (2019) also found an influence between trust and purchase intention. Then the results of the research (Kaur \& Quareshi, 2015; Marriott \& Williams, 2018) found that the trust factor has a positive and significant effect on purchase intention. Customers have a sustainable purchase intention when they trust the seller (Zhao et al., 2019) and trust is an important factor in increasing online shopping interest (Pappas, 2018), because buying interest is the key to the success of e-commerce (Firmansyah \& Ali, 2019).

\section{Pre Research}

To further strengthen the relationship between variables previously discussed, preresearch was carried out. The choice of variables used in conducting pre-research is the variables that are relevant to the object under study. Among the selected variables, including risk perception, application design, convenience, trust, social benefits, $\neg$ new, celebrity endorsement, and brand image. The following can be seen the results of pre-research on online buying interest in the following table. 
Table 1. Pre-Research Results Buying Interest online

\begin{tabular}{clcc}
\hline No & \multicolumn{1}{c}{ Variable } & Total & Percentage \\
\hline 1 & Perception of risk & 15 & 0,17 \\
2 & Application design & 7 & 0,08 \\
3 & Convenience & 10 & 0,11 \\
4 & Trust & 13 & 0,15 \\
5 & Social benefits & 8 & 0,09 \\
6 & e-wom & 16 & 0,18 \\
7 & Celebrity endorser & 5 & 0,05 \\
8 & Brand image $\quad$ Total & 11 & 0,12 \\
\hline & & 85 & 0.95 \\
\hline
\end{tabular}

Source: Pre-Research 2020 Results

Based on the discussion and pre-survey results above, the dominant factors in influencing online buying interest include risk perceptions, trustworthiness, eWOM, and brand image.

\section{Conceptual Framework}

Based on the theoretical study and the relationship between variables, the model or Conceptual Framework of this article in order to construct a hypothesis is as follows:

1) EWOM has a relationship and has an effect on trust, this is based on research results including: (Toto Handiman \& Ali, 2019), (Indarsin \& Ali, 2017), (Matute et al., 2016).

2) EWOM has a relationship and affects Buying Interest, this is based on research results including: (Desfiandi, Desfiandi, et al., 2017), (Lovelock, 2011).

3) Brand image has a relationship and influences trust, this is based on research results including: (Ali et al., 2016), (M \& Ali, 2017), (Ali \& Mapp Pesona, 2016), (Ali, Narulita, et al. ., 2018a), (Novansa \& Ali, 1926), (Toto Handiman \& Ali, 2019), (Toto Handiman \& Ali, 2019), and (Indarsin \& Ali, 2017), (Cheong \& Jang, 2008).

4) Brand Image has a relationship and influences Purchase Intention, this is based on research results including: (Ali et al., 2016), (M \& Ali, 2017), (Ali \& Mapp Pesona, 2016), (Ali, Narulita, et al. al., 2018a), (Novansa \& Ali, 1926), (Toto Handiman \& Ali, 2019), and (Desfiandi, Desfiandi, et al., 2017), (Kazmi \& Mehmood, 2016).

5) Trust has a relationship and influences buying interest, based on the results of research including: (Toto Handiman \& Ali, 2019), (Indarsin \& Ali, 2017), and (Desfiandi, Desfiandi, et al., 2017), (Liu \& Guo, 2017).

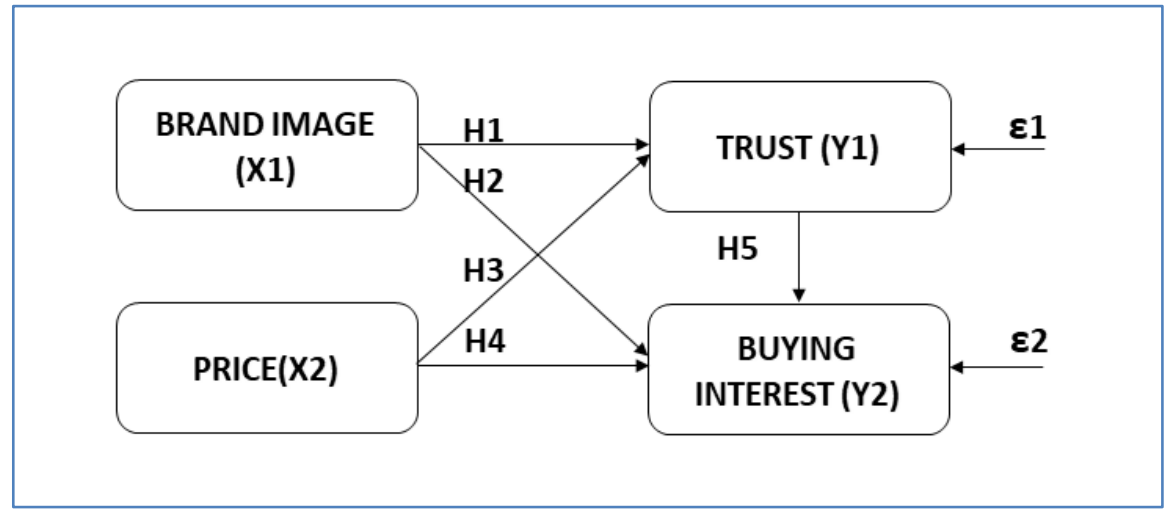

Figure 1. Conceptual Framework 
E-Wom (x1), and Brand Iamge (x2) have an effect on Trust (y1) and Buying Interest (y2) both directly and indirectly.

Apart from the E-Wom variable (x1), and Brand Iamge (x2) there are still other variables that affect Trust (y1) and Buying Interest (y2), including those examined by previous researchers below:

1) Product Quality: (Desfiandi, Fionita, et al., 2017), (M \& Ali, 2017), (Ali, Narulita, et al., 2018a), (M \& Ali, 2017), (Ali, Evi, et al., 2018), (Prihartono \& Ali, 2020), (Riyanto et al., 2017), (Maisah \& Ali, 2020), (Brata et al., 2017), (Thanh Nguyen et al., 2019), (Ali, 2019b), and (Anggita \& Ali, 2017b).

2) Service Quality or Service Delivery : (M \& Ali, 2017), (Limakrisna \& Ali, 2016), (Yunita \& Ali, 2017), (Yunita \& Ali, 2017), (Ali \& Mappesona, 2016), (Ali, Evi, et al., 2018), (Sitio \& Ali, 2019), and (Anggita \& Ali, 2017b).

3) Price Perception): (Christina Catur Widayati et al., 2020), and (C.C. Widayati et al., 2020), (Ali, Narulita, et al., 2018b), (Ikhsani \& Ali, 2017), (Richardo et al., 2020), (Brata et al., 2017), (Anggita \& Ali, 2017a), (Novansa \& Ali, 2017)

4) People/Personnel): (Djoko Setyo Widodo, P. Eddy Sanusi Silitonga, 2017), (Agussalim et al., 2016), (Novansa \& Ali, 1926), (Elmi et al., 2016), (Novansa, Hafizh, Ali, 2017), (Limakrisna et al., 2016), (Octavia et al., 2020), and (Anggita \& Ali, 2017b).

\section{CONCLUSIONS AND SUGGESTIONS}

\section{Conclusion}

Based on the formulation of the article, the results and discussion that are reviewed and discussed in this article, it can be concluded that to build a hypothesis for further research is:

1) EWOM has a relationship and has an effect on trust.

2) EWOM has a relationship and affects Buying Interest.

3) Brand Image has a relationship and adheres to trust.

4) Brand Image has a relationship and influences Buying Interest.

5) Trust has a relationship and influences buying interest.

\section{Suggestions}

Based on the conclusions above, the suggestions in this article both academically and empirically are that there are many other factors that influence consumer buying interest. Therefore, further studies are needed to complement what other factors can influence Buying Interest.

\section{Bibliography}

Abubakar, A. M., \& Ilkan, M. (2016). Impact of online WOM on destination trust and intention to travel: A medical tourism perspective. Journal of Destination Marketing and Management, 5(3), 192-201. https://doi.org/10.1016/j.jdmm.2015.12.005

Agussalim, M., Ayu Rezkiana Putri, M., \& Ali, H. (2016). Analysis work discipline and work spirit toward performance of employees (case study tax office Pratama two Padang).

International Journal of Economic Research.

Ali, H. (2019a). Building Repurchase Intention and Purchase Decision: Brand Awareness and Brand Loyalty Analysis (Case Study Private Label Product in Alfamidi Tangerang).

Saudi Journal of Humanities and Social Sciences. https://doi.org/10.36348/sjhss.2019.v04i09.009

Ali, H. (2019b). Purchase Decision and Repurchase Models: Product Quality and Process Analysis (Case Study of House Ownership Credit Financing in Permata Sharia Bank Jakarta). Scholars Bulletin. https://doi.org/10.36348/sb.2019.v05i09.006

Ali, H., Evi, N., \& Nurmahdi, A. (2018). The Influence of Service Quality , Brand Image and 
Promotion on Purchase Decision at MCU Eka Hospital. Business and Management Studies. https://doi.org/10.21276/sjbms.2018.3.1.12

Ali, H., Limakrisna, N., \& Jamaluddin, S. (2016). Model of customer satisfaction: The empirical study at Bri in Jambi. International Journal of Applied Business and Economic Research.

Ali, H., \& Mappesona, H. (2016). Build brand image: Analysis Service Quality and Product Quality (case study at Giant Citra Raya). International Journal of Economic Research.

Ali, H., Narulita, E., \& Nurmahdi, A. (2018a). Saudi Journal of Business and Management Studies ( SJBMS ) The Influence of Service Quality, Brand Image and Promotion on Purchase Decision at MCU Eka Hospital. Business and Management Studies. https://doi.org/10.21276/sjbms.2018.3.1.12

Ali, H., Narulita, E., \& Nurmahdi, A. (2018b). The Influence of Service Quality, Brand Image and Promotion on Purchase Decision at MCU Eka Hospital. Saudi Journal of Business and Management Studies. https://doi.org/10.21276/sjbms.2018.3.1.12

Anggita, R., \& Ali, H. (2017a). The Influence of Product Quality, Service Quality and Price to Purchase Decision of SGM Bunda Milk. Scholars Bulletin. https://doi.org/10.21276/sb

Anggita, R., \& Ali, H. (2017b). The Influence of Product Quality, Service Quality and Price to Purchase Decision of SGM Bunda Milk (Study on PT. Sarihusada Generasi Mahardika Region Jakarta, South Tangerang District). Scholars Bulletin. https://doi.org/10.21276/sb

Bataineh, A. Q. (2015). The Impact of Perceived e-WOM on Purchase Intention: The Mediating Role of Corporate Image. International Journal of Marketing Studies, 7(1), 126-137. https://doi.org/10.5539/ijms.v7n1p126

Bhandari, M., \& Rodgers, S. (2018). What does the brand say? Effects of brand feedback to negative eWOM on brand trust and purchase intentions. International Journal of Advertising, 37(1), 125-141. https://doi.org/10.1080/02650487.2017.1349030

Brata, B. H., Husani, S., \& Ali, H. (2017). The Importance of Quality Products, Price, Promotion, and Location to Product Purcese Decision on Nitchi At PT. Jaya Swarasa Agung in Central Jakarta. Saudi Journal of Business and Management Studies. https://doi.org/10.21276/sjbms

Bulut, Z. A., \& Karabulut, A. N. (2018). Examining the role of two aspects of eWOM in online repurchase intention: An integrated trust-loyalty perspective. Journal of Consumer Behaviour, 17(4), 407-417. https://doi.org/10.1002/cb.1721

Cheong \&Jang. (2008). Determinants of Internet Usage in Ghanaian Hotels : The Case of the Greater Accra Region ( GAR ) Determinants of Internet Usage in Ghanaian Hotels : The Case of the Greater Accra Region ( GAR ). Journal of Hospitality \& Leisure Marketing, 15(3), 37-41. https://doi.org/10.1300/J150v15n03

Desfiandi, A., Desfiandi, A., \& Ali, H. (2017). Composite Stock Price Index (IHSG) Macro Factor in Investment in Stock (Equity Funds). International Journal of Economics and Financial Issues.

Desfiandi, A., Fionita, I., \& Ali, H. (2017). Implementation of the information systems and the creative economy for the competitive advantages on tourism in the province of Lampung. International Journal of Economic Research.

Djoko Setyo Widodo, P. Eddy Sanusi Silitonga, \& H. A. (2017). Organizational Performance : Analysis of Transformational Leadership Style and Organizational Learning. Saudi Journal of Humanities and Social Sciences. https://doi.org/10.21276/sjhss.2017.2.3.9

Elmi, F., Setyadi, A., Regiana, L., \& Ali, H. (2016). Effect of leadership style, organizational culture and emotional intelligence to learning organization: On the Human Resources Development Agency of Law and Human Rights, Ministry of Law and Human Rights. 
International Journal of Economic Research.

Erkan, I., \& Evans, C. (2016). The influence of eWOM in social media on consumers' purchase intentions: An extended approach to information adoption. Computers in Human Behavior, 61, 47-55. https://doi.org/10.1016/j.chb.2016.03.003

Farivar, S., Turel, O., \& Yuan, Y. (2017). A trust-risk perspective on social commerce use: an examination of the biasing role of habit. Internet Research, 27(3), 586-607. https://doi.org/10.1108/IntR-06-2016-0175

Firmansyah, N., \& Ali, H. (2019). Consumer Trust Model : The Impact of Satisfaction and EService Quality toward Repurchase Intention in E-Commerce. 6256, 552-559. https://doi.org/10.21276/sjhss.2019.4.8.4

Han, B., Kim, M., \& Lee, J. (2018). Exploring consumer attitudes and purchasing intentions of cross-border online shopping in Korea. Journal of Korea Trade, 22(2), 86-104. https://doi.org/10.1108/JKT-10-2017-0093

Ho, S. M., Ocasio-Velázquez, M., \& Booth, C. (2017). Trust or consequences? Causal effects of perceived risk and subjective norms on cloud technology adoption. Computers and Security, 70, 581-595. https://doi.org/10.1016/j.cose.2017.08.004.

Havidz, H. B. H., \& Mahaputra, M. R. (2020). BRAND IMAGE AND PURCHASING DECISION: ANALYSIS OF PRICE PERCEPTION AND PROMOTION (LITERATURE REVIEW OF MARKETING MANAGEMENT). Dinasti International Journal of Economics, Finance \& Accounting, 1(4), 727-741.

Ikhsani, K., \& Ali, D. H. (2017). Keputusan Pembelian: Analisis Kualitas Produk, Harga dan Brand Awareness (Studi Kasus Produk Teh Botol Sosro di Giant Mall Permata Tangerang). In Jurnal SWOT.

Indarsin, T., \& Ali, H. (2017). Attitude toward Using m-Commerce: The Analysis of Perceived Usefulness Perceived Ease of Use, and Perceived Trust: Case Study in Ikens Wholesale Trade, Jakarta - Indonesia. Saudi Journal of Business and Management Studies. https://doi.org/10.21276/sjbms.2017.2.11.7

Indrajaya, H. S., \& Al, H. (2017). Shopping Analysis in on Line Shop with Young People. The International Journal of Social Sciences and Humanities Invention, 4(7), 37973802. https://doi.org/10.18535/ijsshi/v4i8.17

Jalilvand, M. R., Nasrolahi Vosta, L., Kazemi Mahyari, H., \& Khazaei Pool, J. (2017). Social responsibility influence on customer trust in hotels: mediating effects of reputation and word-of-mouth. Tourism Review, 72(1), 1-14. https://doi.org/10.1108/TR-09-2016-0037

Journal, A. M., \& Ali, H. (2017). Scholars Bulletin Analysis of the Company Image and Service Quality through Customer Satisfaction to Customer Loyalty ( A Field Research in PT . Nusantara Water Centre ). 149-158. https://doi.org/10.21276/sb.2017.3.3.10

Kamalul Ariffin, S., Mohan, T., \& Goh, Y. N. (2018). Influence of consumers' perceived risk on consumers' online purchase intention. Journal of Research in Interactive Marketing, 12(3), 309-327. https://doi.org/10.1108/JRIM-11-2017-0100

Kazmi, A., \& Mehmood, Q. S. (2016). The effect of electronic word of mouth communication and brand image on purchase intention: A case of consumer electronics in Haripur, Pakistan. Management Science Letters, 6, 409-508. https://doi.org/10.5267/j.msl.2016.5.003

Kristiani, E., B, C. Y., \& Wang, Y. (2019). for Real-Time Data Streaming Processing on the Edge Computing Architecture (Vol. 1). Springer International Publishing. https://doi.org/10.1007/978-3-030-06158-6

Larasetiati, M., \& Ali, H. (2019). Model of Consumer Trust: Analysis of Perceived Usefulness and toward Repurchase Intention in Online Travel Agent. Journal of Economics and Finance, 3(8), 350-357. https://doi.org/10.21276/sjef.2019.3.8.5

Lee, W. I., Cheng, S. Y., \& Shih, Y. T. (2017). Effects among product attributes, involvement, word-of-mouth, and purchase intention in online shopping. Asia Pacific 
Management Review, 22(4), 223-229. https://doi.org/10.1016/j.apmrv.2017.07.007

Limakrisna, N., \& Ali, H. (2016). Model of Customer Satisfaction: Empirical Study At Fast Food Restaurants in Bandung. International Journal of Business and Commerce.

Limakrisna, N., Noor, Z. Z., \& Ali, H. (2016). Model of employee performance: The empirical study at civil servants in government of west java province. International Journal of Economic Research.

Liu, D., \& Guo, X. (2017). Can trust and social benefit really help? Empirical examination of purchase intentions for wearable devices. Information Development, 33(1), 43-56. https://doi.org/10.1177/0266666916635724.

Mahaputra, M. R. (2017). The influence of trust and customer value to customer satisfaction on bank BRI Branch Soetomo Jambi. Saudi Journal of Business and Management Studies, 2(8).

Mahaputra, M. R. (2020). BUILDING TRUST THROUGH SERVICES QUALITY AND BRAND IMAGE TOWARDS DECISION IN CHOOSING FINANCIAL INSTITUTION AT PT. SUMMIT OTO FINANCE (CASE STUDY PT. SUMMIT OTO FINANCE KEDOYA BRANCH, WEST JAKARTA). Dinasti International Journal of Education Management And Social Science, 2(2), 231-241.

M, A., \& Ali, H. (2017). MODEL KEPUASAN PELANGGAN: ANALISIS KUALITAS PRODUK DAN KUALITAS LAYANAN TERHADAP CITRA MEREK PADA GIANT CITRA RAYA JAKARTA. Jurnal Manajemen. https://doi.org/10.24912/jm.v21i3.254

Maisah, \& Ali, H. (2020). Entrepreneurship culture development process: Implementation of Islamic education values in the Batik Jambi (case study in Seberang Jambi community). Talent Development and Excellence.

Marriott, H. R., \& Williams, M. D. (2018). Exploring consumers perceived risk and trust for mobile shopping: A theoretical framework and empirical study. Journal of Retailing and Consumer Services, 42(January), 133-146. https://doi.org/10.1016/j.jretconser.2018.01.017

Matute, J., Polo-Redondo, Y., \& Utrillas, A. (2016). The influence of EWOM characteristics on online repurchase intention. Online Information Review, 40(7), 1090-1110. https://doi.org/10.1108/oir-11-2015-0373

Mosunmola, A., Adegbuyi, O., Kehinde, O., Agboola, M., \& Olokundun, M. (2019). Percieved value dimensions on online shopping intention: The role of trust and culture. Academy of Strategic Management Journal, 18(1), 1-20.

Novansa, Hafizh, Ali, H. (2017). Purchase Decision Model: Analysis of Brand Image, Brand Awareness and Price (Case Study SMECO Indonesia SME products). Saudi Journal of Humanities and Social Sciences.

Novansa, H., \& Ali, H. (1926). Purchase Decision Model: Analysis of Brand Image, Brand Awareness and Price (Case Study SMECO Indonesia SME products). Saudi Journal of Humanities and Social Sciences. https://doi.org/10.21276/sjhss

Novansa, H., \& Ali, H. (2017). Purchase Decision Model: Analysis of Brand Image, Brand Awareness and Price (Case Study SMECO Indonesia SME products). Saudi Journal of Humanities and Social Sciences. https://doi.org/10.21276/sjhss

Octavia, A., Sriayudha, Y., \& Ali, H. (2020). Innovation capability and supply chain management: Empirical study of Indonesian traditional herbal medicine products. International Journal of Supply Chain Management.

Pappas, I. O. (2018). User experience in personalized online shopping: a fuzzy-set analysis. European Journal of Marketing, 52(7-8), 1679-1703. https://doi.org/10.1108/EJM-102017-0707

Pappas, N. (2016). Marketing strategies, perceived risks, and consumer trust in online buying behaviour. Journal of Retailing and Consumer Services, 29, 92-103. 
https://doi.org/10.1016/j.jretconser.2015.11.007

Park, J., Amendah, E., Lee, Y., \& Hyun, H. (2019). M-payment service: Interplay of perceived risk, benefit, and trust in service adoption. Human Factors and Ergonomics In Manufacturing, 29(1), 31-43. https://doi.org/10.1002/hfm.20750

Prihartono, \& Ali, H. (2020). The promises ethics and marketing concept strategy as a competitive advantage on private higher education (A survey on perception of product attributes and promotion mix in Indonesia). Talent Development and Excellence.

Richardo, Hussin, M., Bin Norman, M. H., \& Ali, H. (2020). A student loyalty model: Promotion, products, and registration decision analysis-Case study of griya english fun learning at the tutoring institute in wonosobo central Java. International Journal of Innovation, Creativity and Change.

Riyanto, S., Adila, L., \& Ali, H. (2017). The Effect of Incentives And Job Enthusiasm To Productivity of Go-Jek Driver At PT . Go-Jek Indonesia. Journal of Research in Business and Management.

Setyadi, D. A. (2017). Build Customer Loyalty with CRM and Brand Image (Case Study on Giant Citra Raya). IOSR Journal of Business and Management, 19(01), 35-42. https://doi.org/10.9790/487x-1901043542

Silva, J., Pinho, J. C., Soares, A., \& Sá, E. (2019). Antecedents of online purchase intention and behaviour: Uncovering unobserved heterogeneity. Journal of Business Economics and Management, 20(1), 131-148. https://doi.org/10.3846/jbem.2019.7060

Sitio, T., \& Ali, H. (2019). Patient Satisfaction Model and Patient Loyalty: Analysis of Service Quality and Facility (Case Study at Rawamangun Special Surgery Hospital). Scholars Bulletin. https://doi.org/10.36348/sb.2019.v05i10.002

Suharjadi, P. D., Pascasarjana, P., Manajemen, M., \& Mercu, U. (2017). Jurnal SWOT, Volume VII , No 3 , September 2017 Jurnal SWOT, Volume VII , No 3, September 2017. VII(3), 629-645.

Thanh Nguyen, P., Ali, H., \& Agung Hudaya. (2019). MODEL BUYING DECISION AND REPEAT PURCHASE: PRODUCT QUALITY ANALYSIS (Case Study of Bank Permata Syariah Jakarta KPR Financing Customers). Dinasti International Journal of Management Science. https://doi.org/10.31933/dijms.v1i1.29

Toto Handiman, U., \& Ali, H. (2019). The Influence of Brand Knowledge and Brand Relationship On Purchase Decision Through Brand Attachment. In International Journal of Business Marketing and Management (IJBMM).

Widayati, C.C., Ali, H., Permana, D., \& Nugroho, A. (2020). The role of destination image on visiting decisions through word of mouth in urban tourism in Yogyakarta. International Journal of Innovation, Creativity and Change, 12(3).

Widayati, Christina Catur, Ali, H., Permana, D., \& Nugroho, A. (2020). The role of destination image on visiting decisions through word of mouth in urban tourism in Yogyakarta. International Journal of Innovation, Creativity and Change.

Yang, Q., Pang, C., Liu, L., Yen, D. C., \& Michael Tarn, J. (2015). Exploring consumer perceived risk and trust for online payments: An empirical study in China's younger generation. Computers in Human Behavior, 50, 9-24. https://doi.org/10.1016/j.chb.2015.03.058

Yu, C. C., Lin, P. J., \& Chen, C. S. (2013). How brand image, country of origin, and selfcongruity influence internet users' purchase intention. Social Behavior and Personality, 41(4), 599-611. https://doi.org/10.2224/sbp.2013.41.4.599

Yunita, D., \& Ali, H. (2017). Model of Purchasing Decision ( Renting ) of Generator Set : Analysis of Product Quality, Price an Service at PT . Hartekprima Listrindo.

Economics, Business and Management. https://doi.org/10.21276/sjebm.2017.4.11.12

Zhao, J. Di, Huang, J. S., \& Su, S. (2019). The effects of trust on consumers' continuous purchase intentions in $\mathrm{C} 2 \mathrm{C}$ social commerce: A trust transfer perspective. Journal of 
Retailing and Consumer Services, 50(January), 42-49.

https://doi.org/10.1016/j.jretconser.2019.04.014 